\title{
LETTER
}

\section{Use of hydroxyethyl starch in critically ill patients}

\author{
Guillermo Bugedo $^{1 *}$ and Carlos Romero ${ }^{2}$ \\ See related research by Meybohm et al., http://ccforum.com/content/17/4/R166
}

We read with interest the article by Meybohm and colleagues regarding the use of hydroxyethyl starch (HES) in critically ill patients [1]. Although we may agree with their conclusion that the most important question is whether or not HES may be harmful, we cannot agree with their suggestion on further clinical use based only on strict indication for HES or a safety checklist.

In recent major randomized trials, HES reversed hypovolemia and improved hemodynamic parameters earlier than crystalloids [2-4]. However, despite this physiologic benefit of HES, clinical results move in the opposite direction. Strong signals of a higher incidence of organ dysfunction or higher mortality in critically ill patients in large clinical trials cannot be disregarded $[2,3,5]$.

Before going into further clinical trials or suggesting strict indications, we should first re-evaluate the effect of HES on experimental models. Unless a clear advantage of HES over crystalloid is demonstrated, which so far has not been, we must give the benefit of the doubt to the patients and not to the drug.

\section{Abbreviations}

HES: Hydroxyethyl starch.

\section{Competing interests}

$C R$ received lecture and consultancy fees and travel expenses from Fresenius-Kabi. GB declares that they have no competing interests.

\section{Author details}

'Hospital Clínico Pontificia Universidad Católica de Chile, Santiago, Chile.

${ }^{2}$ Hospital Clínico Universidad de Chile, Santiago, Chile.

\section{Published: 02 Oct 2013}

\section{References}

1. Meybohm P, Van Aken H, De Gasperi A, De Hert S, Della Rocca G, Girbes AR, Gombotz H, Guidet B, Hasibeder W, Hollmann MW, Ince C, Jacob M, Kranke P, Kozek-Langenecker S, Loer SA, Martin CD, Siegemund M, Wunder C, Zacharowski K: Re-evaluating currently available data and suggestions for planning randomised controlled studies regarding the use of hydroxyethyl-starch in critically ill patients - a multidisciplinary statement. Crit Care 2013, 17:R166.

\footnotetext{
*Correspondence: gbugedo@gmail.com

${ }^{1}$ Hospital Clínico Pontificia Universidad Católica de Chile, Santiago, Chile Full list of author information is available at the end of the article
}

2. Brunkhorst FM, Engel C, Bloos F, Meier-Hellmann A, Ragaller M, Weiler N, Moerer O, Gruendling M, Oppert M, Grond S, Olthoff D, Jaschinski U, John S, Rossaint R, Welte T, Schaefer M, Kern P, Kuhnt E, Kiehntopf M, Hartog C, Natanson C, Loeffler M, Reinhart K, German Competence Network Sepsis (SepNet): Intensive insulin therapy and pentastarch resuscitation in severe sepsis. N Engl J Med 2008, 358:125-139.

3. Myburgh JA, Finfer S, Bellomo R, Billot L, Cass A, Gattas D, Glass P, Lipman J, Liu B, McArthur C, McGuinness S, Rajbhandari D, Taylor CB, Webb SA, CHEST Investigators; Australian and New Zealand Intensive Care Society Clinical Trials Group: Hydroxyethyl starch or saline for fluid resuscitation in intensive care. N Engl J Med 2012, 367:1901-1911.

4. Guidet B, Martinet O, Boulain T, Philippart F, Poussel JF, Maizel J, Forceville $X$, Feissel M, Hasselmann M, Heininger A, Van Aken H: Assessment of hemodynamic efficacy and safety of $6 \%$ hydroxyethylstarch $130 / 0.4 \mathrm{vs}$. $0.9 \% \mathrm{NaCl}$ fluid replacement in patients with severe sepsis: the CRYSTMAS study. Crit Care 2012, 16:R94.

5. Perner A, Haase N, Guttormsen AB, Tenhunen J, Klemenzson G, Aneman A, Madsen KR, Moller MH, Elkjaer JM, Poulsen LM, Bendtsen A, Winding R, Steensen M, Berezowicz P, Søe-Jensen P, Bestle M, Strand K, Wiis J, White JO, Thornberg KJ, Quist L, Nielsen J, Andersen LH, Holst LB, Thormar K, Kjældgaard AL, Fabritius ML, Mondrup F, Pott FC, Møller TP, et al: Hydroxyethyl starch 130/0.42 versus Ringer's acetate in severe sepsis. N Engl J Med 2012, 367:124-134.

$10.1186 / \mathrm{cc} 13032$

Cite this article as: Bugedo and Romero: Use of hydroxyethyl starch in critically ill patients. Critical Care 2013, 17:455 